\title{
ALTERNATIF PETA BATAS LAUT DAERAH BERDASARKAN PERATURAN MENTERI DALAM NEGERI NOMOR 76 TAHUN 2012 (STUDI KASUS : SENGKETA PULAU GALANG PERBATASAN ANTARA KOTA SURABAYA DAN KABUPATEN GRESIK)
}

\author{
Ria Widiastuty ${ }^{1}$, Khomsin $^{1}$, Teguh Fayakun ${ }^{2}$, Eko Artanto ${ }^{2}$ \\ ${ }^{1}$ Program Studi Teknik Geomatika, FTSP, ITS-Sukolilo, Surabaya, 60111 \\ Email : riawidiastuty@gmail.com \\ ${ }^{2}$ Pusat Pemetaan Batas Wilayah, Badan Informasi Geospasial, Cibinong
}

\begin{abstract}
Abstrak
Batas kewenangan daerah di laut, memiliki arti penting bagi kabupaten/kota dan pemerintah propinsi terkait dengan penyelenggaraan otonomi daerah. Batas daerah yang tidak jelas dapat memicu konflik di wilayah perbatasan dan menghambat penyelenggaraan fungsi pemerintahan daerah. Bila tidak segera diselesaikan maka berpotensi menurunkan tingkat pelayanan pemerintah kepada masyarakat. Penetapan batas laut daerah diperlukan agar tidak terjadi tumpang tindih kewenangan pemberian hak sehingga dapat menghindari konflik yang akan terjadi.
\end{abstract}

Pada Peraturan Menteri Dalam Negeri Nomor 76 tahun 2012 dijelaskan bahwa pembagian wilayah kewenangan propinsi sejauh 12 mil dan sepertiganya adalah wilayah kabupaten/kota. Penelitian ini ditujukan untuk menentukan batas pengelolaan laut di sekitar daerah perbatasan Kota Surabaya dan Kabupaten Gresik yang terdapat sebuah pulau hasil endapan Kali Lamong yaitu Pulau Galang. Pulau ini sedang menjadi konflik dan menjadi perebutan hak milik antar dua daerah tersebut. Hasil penelitian ini adalah peta batas pengelolaan laut di sekitar daerah Kota Surabaya dan Kabupaten Gresik dengan berbagai alternatif penarikan batas yang sesuai dengan pedoman penegasan batas secara kartometrik pada Peraturan Menteri Dalam Negeri Nomor 76 tahun 2012 dengan menggunakan prinsip equidistance dan median line. Dalam penelitian ini terdapat empat alternatif diantaranya, penarikan garis batas laut jika Pulau Galang dianggap tidak ada, penarikan garis batas laut jika Pulau Galang dibagi sama luas, penarikan garis batas laut jika Pulau Galang masuk Kota Surabaya dan penarikan garis batas laut jika Pulau Galang masuk Kabupaten Gresik. Sehingga dapat disimpulkan bahwa kejelasan kepemilikkan Pulau Galang dan kejelasan administrasi batas laut daerah sangat dibutuhkan karena keberadaan pulau ini berpengaruh terhadap batas pengelolaan laut daerah antara Kota Surabaya maupun Kabupaten Gresik secara keseluruhan.

Kata Kunci : Batas Laut Daerah, Metode Kartometrik, Equidistance, Median Line, Permendagri No. 76 Tahun 2012

\section{PENDAHULUAN}

\section{Latar Belakang}

Negara Indonesia memiliki wilayah dengan luas keseluruhan $8.292 .983 \mathrm{~km}^{2}$ (Pusat Pemetaan Batas Wilayah, BIG, 2012). Dengan wilayah seluas itu, Indonesia juga memiliki sumberdaya alam berlimpah yang tersebar di daratan dan lautan. Untuk mengoptimalkan pengolahan dan pengelolaan sumberdaya alam tersebut dibutuhkan batas wilayah untuk memastikan hak dan kepemilikan suatu pemerintahan. Batas wilayah definitif yang didasarkan pada ketetapan hukum berperan penting untuk tata kelola pemerintahan, pertahanan, keamanan, perijinan, pengelolaan sumberdaya alam, dan lain-lain.
Undang-Undang Nomor 4 Tahun 2011 tentang Informasi Geospasial mengamanatkan seluruh pemetaan di Indonesia mengacu pada satu referensi (One Map Policy), yaitu Informasi Geospasial Dasar yang diwujudkan dalam Jaring Kontrol Geodesi dan peta dasar, dimana batas wilayah merupakan salah satu unsur di dalamnya (Pusat Pemetaan Batas Wilayah, BIG, 2012). Oleh karena itu, penegasan batas wilayah baik batas internasional maupun batas daerah perlu dituntaskan untuk mendukung pembangunan nasional. Kejelasan dan ketegasan batas sangat penting dalam rangka menjamin adanya kepastian kewenangan, terutama berkenaan dengan kepentingan penanganan eksplorasi dan eksploitasi 
sumberdaya alam, pertahanan, keamanan, sosial budaya, dan teknologi.

Pulau Galang bukan merupakan pulau yang terlahir pada masa silam. Pulau ini tergolong pulau kecil yang timbul dengan sendirinya. Pulau ini terjadi karena sedimentasi endapan lumpur Sungai Lamong yang berlangsung sejak tahun 1960-an. Sebelumnya tidak ada pulau di kawasan tersebut. Dengan berbagai potensi Pulau Galang, kini Pemerintah Kota Surabaya maupun Pemerintah Kabupaten Gresik saling klaim sebagai pemilik sah Pulau Galang. Dari sudut georafis memang pulau tersebut adalah milik Pemerintah Kota Surabaya, namun Pemerintah Kabupaten Gresik mengklaim memiliki pulau tersebut dengan dalih mempunyai 3 sertifikat kepemilikan. Karena masih dalam perselisihan maka pulau tersebut di status quo-kan, yaitu status pulau milik Provinsi Jawa Timur. Sebab dengan status tersebut merupakan jalan terbaik daripada harus berebutan pulau (Pemerintah Kota Surabaya, 2003). Guna untuk mendapatkan solusi pemecahan permasalahan yang ada di batas wilayah laut daerah Kota Surabaya dan Kabupaten Gresik yang memperebutkan Pulau Galang, maka perlu adanya kajian penanganan batas wilayah laut daerah Kota Surabaya dan Kabupaten Gresik dalam rangka menjaga keutuhan NKRI.

Penelitian tugas akhir ini bertujuan untuk mengetahui batas laut di daerah sekitar antara Kota Surabaya dan Kabupaten Gresik ini penting karena perlunya kepastian posisi, eksistensi, dan status hukum suatu batas laut daerah. Penelitian ini menggunakan metode kartometrik, yakni penentuan batas wilayah yang dilakukan di atas peta. Penegasan batas daerah tidak harus dengan memasang pilar batas di sepanjang batas, terutama untuk segmen batas yang berupa batas alam yang sulit dijangkau.

\section{Perumusan Masalah}

Perumusan masalah yang diangkat dalam penelitiantugas akhir ini adalah sebagai berikut:

a. Bagaimana hasil penentuan batas daerah Kota Surabaya dan Kabupaten Gresik dalam hal ini kasus sengketa Pulau Galang dengan menggunakan metode kartometrik sesuai dengan Peraturan Menteri Dalam Negeri Nomor 76 Tahun 2012?

b. Bagaimana analisa zona batas wilayah pengelolaan laut Kota Surabaya dan Kabupaten Gresik terkait dengan solusi sengketa Pulau Galang?

\section{METODOLOGI PENELITIAN \\ Lokasi Penelitian}

Lokasi penelitian ini mengambil wilayah perbatasan antara Kota Surabaya dan Kabupaten Gresik, yang mana terdapat pulau hasil sedimentasi bernama Pulau Galang. Kota Surabaya ini memiliki posisi geografis pada $07^{\circ} 9^{\prime}$ Lintang Selatan (LS) sampai dengan $07^{\circ} 21^{\prime}$ Lintang Selatan (LS) dan $112^{\circ} 36^{\prime}$ Bujur Timur (BT) sampai dengan $112^{\circ} 54^{\prime}$ Bujur Timur (BT), sedangkan Kabupaten Gresik berada pada posisi geografis antara $1^{\circ}$ Lintang Selatan (LS) sampai $8^{\circ}$ Lintang Selatan (LS) dan $112^{\circ}$ Bujur Timur (BT) sampai $113^{\circ}$ Bujur Timur (BT). Pulau Galang terletak di perbatasan Kota Surabaya dan Kabupaten Gresik.

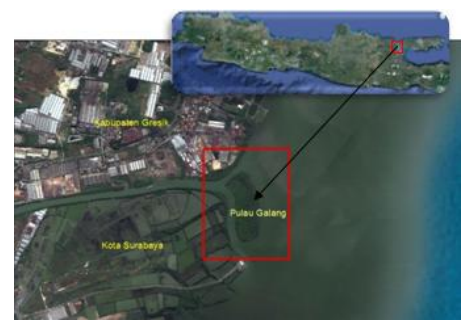

Gambar 1. Lokasi penelitian

\section{Data dan Peralatan Data}

Data yang digunakan dalam penelitian ini adalah:

a. Peta LPI skala 1:50.000 sesuai daerah penelitian yang dikeluarkan oleh Badan Informasi Geospasial (BIG) Indonesia. Peta Lingkungan Pantai Indonesia sekitar Pulau Galang perbatasan antara daerah Kota Surabaya dan Kabupaten Gresik, yakni LPI tahun 2002 dengan lembar 1608-01, 160802,1608-03, 1608-04, 1608-04 format raster (*.jpg)

b. Citra resolusi tinggi dari Google Earth tahun 2006 sekitar Pulau Galang perbatasan antara daerah Kota Surabaya dan Kabupaten Gresik dalam bentuk *.geotiff 
c. Garis pantai Indonesia tahun 2013 dari Badan Informasi Geospasial (BIG) dalam bentuk shapefile (*.shp)

d. Peta Rupa Bumi Indonesia (data toponimi, tutupan lahan, dan administrasi) dari Badan Informasi Geospasial (BIG) dalam bentuk shapefile (*.shp) dengan skala $1: 25.000$

e. Peraturan Menteri Dalam Negeri Nomor 76 Tahun 2012

f. Data dan informasi pendukung terkait informasi sengketa Pulau Galang dari pemerintah Kota Surabaya dan Kabupaten Gresik

\section{Peralatan}

Peralatan yang digunakan dalam penelitian ini adalah Personal Computer (PC)dan software pengolahan data spasial.

\section{Tahapan Penelitian}

Berikut ini adalah penjelasan diagram alir tahapan kegiatan penelitian pada Gambar 2 :

a. Pada tahap awal pengolahan data ini mengumpulkan peta-peta penelitian yang telah disebutkan pada tahap pelaksanaan di atas.

b. Data Peta LPI tahun 2002 format raster harus diubah menjadi format vektor dengan melalui proses digitasi menggunakan software pengolahan data digital

c. Penentuan titik-titik dasar (basepoint) dilakukan di sepanjang garis pantai di sekitar Pulau Galang perbatasan Kota Surabaya dan Kabupaten Gresik, juga penentuan basepoint pada pantai Kabupaten Bangkalan.

d. Penentuan batas pengelolaan laut daerah sengketa Pulau Galang perbatasan antara Kota Surabaya dan Kabupaten Gresik menggunakan dua metode yaitu metode equidistance (sama jarak) dan median line (garis tengah) sesuai dengan Peraturan Menteri Dalam Negeri Nomor 76 Tahun 2012. Dalam pembuatan konstruksi batas secara manual dengan prinsip 3 points, yakni tiga jarak yang sama dengan satu titik tengah, untuk pemilihan basepoint dilakukan secara subjektif dengan criteria kedua titik saling terlihat dan pembuatan lingkaran 3 point yang tidak banyak memotong garis pantai. e. Dalam penelitian ini menghasilkan peta yang memuat beberapa alternatif garis batas pengelolaan laut daerah terkait dengan keberadaan Pulau Galang, diantaranya alternatif pertama Pulau Galang dianggap tidak ada kemudian ditarik garis median line dari Sungai Lamong menuju laut bebas, alternatif kedua Pulau Galang dibagi sama luas, alternatif ketiga Pulau Galang masuk daerah Kota Surabaya, alternatif terakhir Pulau Galang masuk daerah Kabupaten Gresik.

f. Analisa yang dilakukan adalah analisa luas tampalan zona pengelolaan laut daerah pada pembagian Pulau Galang dari empat alternatif yang dibuat dalam penelitian ini.

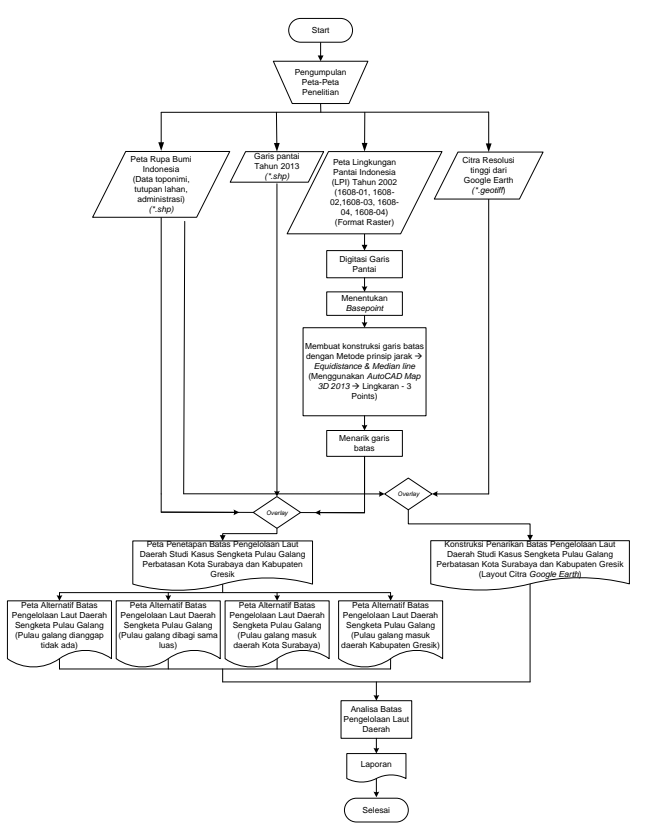

Gambar 2. Diagram Alir Penelitian

\section{HASIL DAN ANALISA}

\section{a. Hasil Digitasi Garis Pantai}

Peta dasar yang digunakan untuk menentukan titik-titik dasar atau titik-titik batas wilayah daerah laut secara kartometrik harus mempunyai sistem yang sama untuk seluruh wilayah Indonesia. Penggunaan peta dasar yang sistemnya berbeda-beda oleh setiap daerah akan sangat memungkinkan timbulnya konflik batas antara daerah-daerah yang berbatasan. Dalam hal ini harus ada standarisasi secara nasional untuk datum geodetik, elipsoid referensi, sistem proyeksi serta skala bagi peta 
dasar yang akan digunakan untuk penetapan batas daerah.

Pada penelitian ini peta dasar yang digunakan adalah peta LPI keluaran Badan Informasi Geospasial tahun 2002 dan Peta LPI Indonesia tahun 2013 yang sudah mempunyai elipsoid referensi dan proyeksi yang sama yakni datum WGS 1984 dan proyeksi UTM. Pada Peta LPI tahun 2002 koordinat graticule sudah menggunakan geodetik $(\varphi, \lambda)$ dan Universal Tranverse Mercator $(\mathrm{x}, \mathrm{y})$, maka dari itu tidak perlu mentransformasi koordinat karena hasil yang diinginkan adalah dalam sistem Universal Tranverse Mercator ( $\mathrm{x}, \mathrm{y})$.

Dalam konteks penentuan batas daerah, UU 32/2004 menyatakan bahwa batas kewenangan suatu provinsi di laut adalah sejauh dua belas mil laut yang diukur dari garis pantai dan kewenangan daerah kabupaten dan daerah kota (kotamadya) adalah sejauh sepertiga dari batas laut provinsi dari garis pantai. Perlu diketahui bahwa dalam UU 32/2004 ini tidak dijelaskan tentang spesifikasi garis pantai yang harus digunakan.

Dalam penentuan garis pantai, hal ini mencakup standarisasi dan spesifikasi teknis untuk survei batimetri dan pengamatan pasut yang perlu dilakukan. Untuk kepraktisan dan juga untuk meminimalkan biaya pelaksanaan penetapan batas daerah, maka bagi wilayah laut yang sudah dipetakan dan sudah mempunyai peta laut, kontur nol yang merupakan bidang muka surutan peta laut dapat digunakan sebagai muka air rendah untuk penentian garis pantai yang nantinya akan digunakan untuk penetapan titik awal dan garis dasar.

Peta dasar yang digunakan pada penelitian ini yaitu peta LPI muka air terendah menggunakan MSL (Mean Sea Level). Kontur nol pada peta LPI lembar Gresik dan Kwanyar yang digunakan dalam penelitian ini diukur berdasarkan muka laut di Surabaya. Kontur nol pada peta LPI lembar Pasuruan dan Probolinggo diukur berdasarkan muka laut di Tanjung Perak. Dan kontur nol pada peta LPI lembar Sampang diukur berdasarkan muka laut di Sampang.

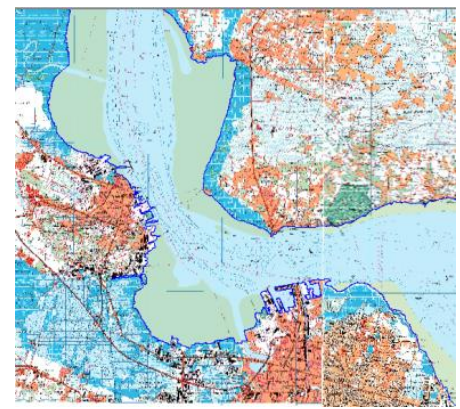

Gambar 3. Hasil Digitasi Peta LPI Tahun 2002

Gambar 3 merupakan hasil dari digitasi Peta LPI tahun 2002. Dalam penelitian ini mendigitasi garis pantai mengikuti garis terluar dari Peta LPI tanpa menghiraukan pengertian dari garis pangkal dan semacamnya, karena pada UU $32 / 2004$ penarikan garis batas diukur dari garis pantai tanpa dijelaskan secara rinci spesifikasinya. Dengan demikian dapat dilakukan pekerjaan bahwa penarikan batas laut dimulai dari garis pantai dengan muka laut terendah pada peta dasar yang digunakan yakni Peta LPI.

\section{b. Hasil Penentuan Titik Kartometrik}

Penentuan batas dengan metode kartometrik adalah melakukan plotting atau penarikan batas di atas peta berskala terbesar yang tersedia, sehingga penampakkan kondisi di lapangan masih tergambar dengan jelas. Pada dasarnya garis batas terbentuk oleh titik-titik yang sudah ditentukan, untuk itu sebelum penarikan batas secara kartometrik maka diperlukan titik-titik kartometrik. Penentuan titik dasar di atas Peta LPI diambil dari garis pantai dengan memilih titik dasar yang paling mencolok, mudah terlihat, dan tidak terlalu banyak memotong daratan. Sehingga dihasilkan empat alternatif garis batas terkait kasus sengketa Pulau Galang perbatasan antara Kota Surabaya dan Kabupaten Gresik. Untuk itu terdapat empat daftar koordinat titik kartometrik yang dihasilkan.

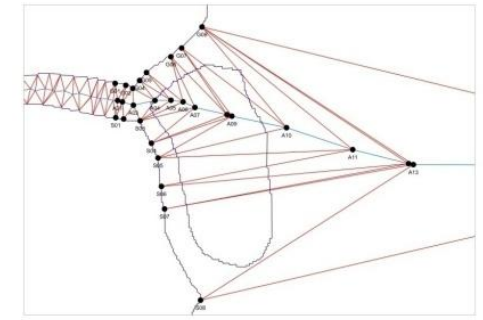

Gambar 4. Contoh Hasil Titik Kartometrik 
Keterangan :

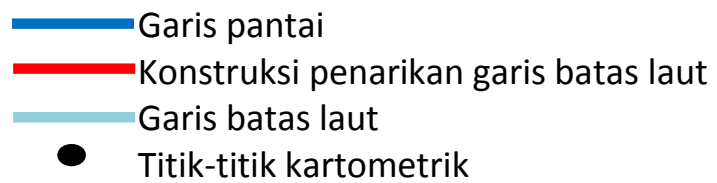

Pada gambar contoh hasil titik kartometrik di atas terlihat bahwa garis batas terbentuk dari titik-titik kartometrik. Untuk titik kartometrik beranotasi A merupakan hasil dari penarikan garis dari titik-titik kartometrik beranotasi $G$ (Gresik) dan S (Surabaya) dengan metode equidistance dan median line. Perlu diketahui dalam penarikan konstruksi garis batas tersebut secara manual menggunakan prinsip 3 points yakni 3 titik dengan jarak yang sama

\section{c.Analisa Penarikan Batas dengan Metode Equidistance dan Median Line}

Equidistance terbentuk dari konstruksi/gabungan dari equidistance lines, kemudian gabungan (garis) pertemuan titik tengah akan membentuk garis batas yang disebut median line. Pada prinsipnya penarikan batas sama jarak dengan median line maupun equidistance adalah sama, yaitu perpotongan aris antar pasangan titik-titik dasar. Pemilihan titik-titik dasar sangat penting diusahakan titiktitik dasar adalah titik terluar dari garis pantai (titik salient). Konfigurasi equidistance line yang baik dan sama jarak didapatkan dari pasanganpasangan titik dasar yang memiliki jarak yang sama dengan titik batas acuan. Semakin banyak pasangan titik dasar semakin baik pula konfigurasi penarikan garis batas sama jaraknya.

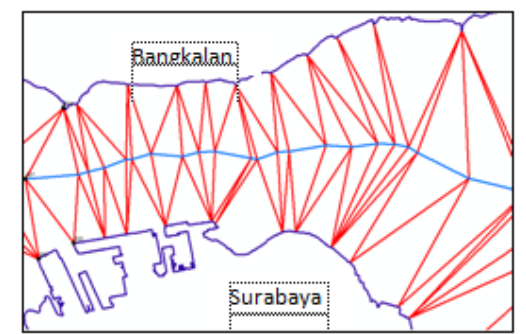

Gambar 5. Contoh Hasil Penarikan Batas Laut dengan Metode Median Line

Pada Gambar 5 merupakan salah satu hasil penarikan batas laut dengan metode median line, yakni prinsip garis tengah antar daratan Kota Surabaya dan Kabupaten Bangkalan. Perlu 44 diketahui bahwa penentuan dua titik awal merupakan titik pertama yang menentukan titik berikutnya sehingga terbentuk titik tengah-titik tengah dan kemudian ditarik garis membentuk median line.

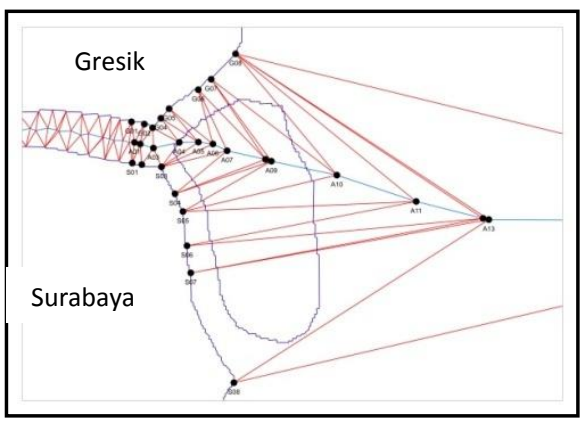

Gambar 6. Contoh Penarikan Batas Laut dengan Metode Equidistance

Pada Gambar 6 merupakan salah satu hasil penarikan batas laut dengan metode equidistance, yakni prinsip sama jarak antara Kota Surabaya dan Kabupaten Gresik. Titik-titik yang terbentuk dengan prinsip 3 points sama jarak, titik pertemuan antar 3 titik tersebut dihubungkan dan terbentuklah garis batas.

\section{c. Analisa Kepemilikan Pulau Galang Berdasarkan Penarikan Batas Pengelolaan Laut Daerah}

1. Penarikan batas pengelolaan laut daerah jika pulau galang dianggap tidak ada

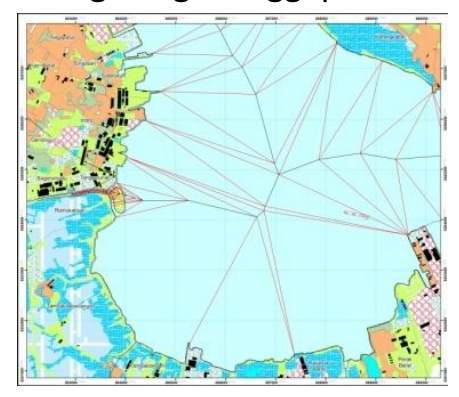

Gambar 7. Hasil Penarikan Batas Pengelolaan Laut jika Pulau Galang dianggap Tidak Ada

Luas keseluruhan dari Pulau Galang yakni $103.326 \mathrm{~m}^{2}$ atau setara dengan 10,3 hektar. Untuk alternatif ini Pulau Galang dianggap tidak ada, kemudian ditarik garis batas laut daerah dan didapatkan luas Pulau Galang dari sisi Kota Surabaya yakni $83.091 \mathrm{~m}^{2}$ atau 8,3 hektar sedangkan luas Pulau Galang dari sisi Kabupaten Gresik yakni $20.234 \mathrm{~m}^{2}$ 
atau 2,0 hektar. Hasil tersebut menunjukkan bahwa Pulau Galang terbagi menjadi dua kepemilikan dengan luas yang telah disebutkan di atas $180 \%$ kepemilikan Kota Surabaya dan 20\% kepemilikan Kabupaten Gresik). Dengan demikian akan berpengaruh pada batas pengelolaan laut secara keseluruhan antara Kota Surabaya dan Kabupaten Gresik sesuai yang terlihat pada Gambar 7.

2. Penarikan batas pengelolaan laut daerah jika pulau galang dibagi sama luas

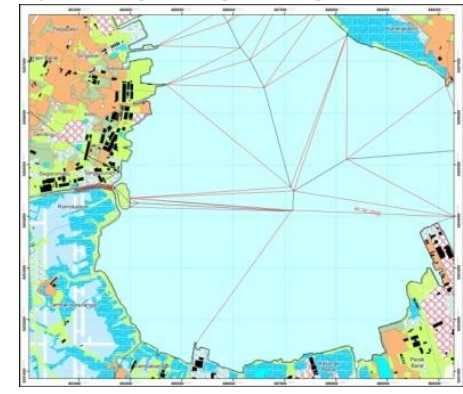

Gambar 8. Hasil Penarikan Batas Pengelolaan Laut jika Pulau Galang dibagi Sama Luas

Luas keseluruhan dari Pulau Galang yakni $103.326 \mathrm{~m}^{2}$ atau setara dengan 10,3 hektar. Pada alternatif ini Pulau Galang juga memiliki dua kepemilikan yaitu Kota Surabaya dan Kabupaten Gresik namun dengan porsi masingmasing $50 \%$ dari total luas Pulau Galang. Pulau Galang dibagi sama luas, yakni masing-masing untuk daerah Kota Surabaya dan Kabupaten Gresik 51.663 $\mathrm{m}^{2}$ atau 5,16 hektar. Dengan demikian akan berpengaruh pada batas pengelolaan laut secara keseluruhan antara Kota Surabaya dan Kabupaten Gresik sesuai yang terlihat pada Gambar 8.

3. Penarikan batas pengelolaan laut daerah jika pulau galang masuk daerah kota surabaya

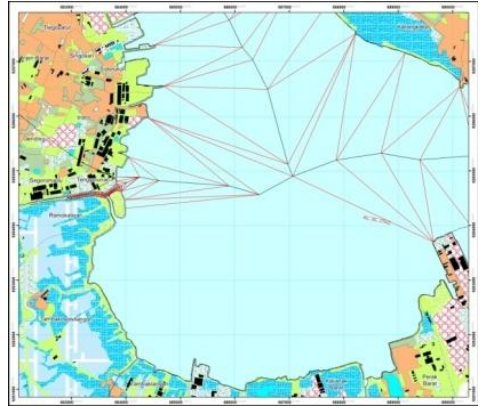

Gambar 9. Hasil Penarikan Batas Pengelolaan Laut jika Pulau Galang Masuk Daerah Kota Surabaya

Pada alternatif penarikan batas pengelolaan laut daerah ini, jika Pulau Galang masuk daerah Kota Surabaya, dengan demikian begitu luas keseluruhan dari Pulau Galang yakni $103.326 \mathrm{~m}^{2}$ atau setara dengan 10,3 hektar menjadi bagian dari Kota Surabaya seutuhnya. Dari arah Kali Lamong ditarik garis batas laut daerah, kemudian dilanjutkan penarikan batas laut dengan opsi Pulau Galang masuk daerah Kota Surabaya.

4. Penarikan batas pengelolaan laut daerah jika pulau galang masuk daerah kabupaten gresik

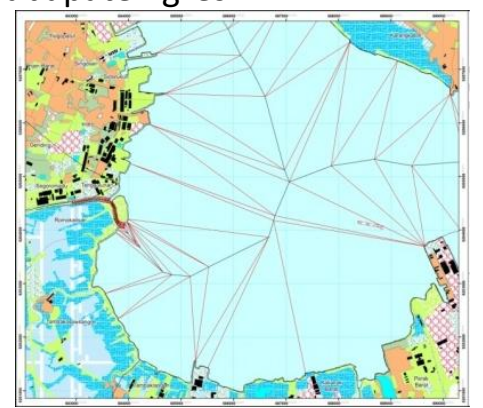

Gambar 10. Hasil Penarikan Batas Pengelolaan Laut jika Pulau Masuk Daerah Kabupaten Gresik

Pada alternatif penarikan batas pengelolaan laut daerah ini, jika Pulau Galang masuk daerah Kabupaten Gresik, dengan demikian begitu luas keseluruhan dari Pulau Galang yakni $103.326 \mathrm{~m}^{2}$ atau setara dengan 10,3 hektar menjadi bagian dari Kabupaten Gresik seutuhnya. Dari arah Kali Lamong ditarik garis batas laut daerah, kemudian dilanjutkan penarikan batas laut dengan opsi Pulau Galang masuk daerah Kabupaten Gresik 


\section{PENUTUP}

\section{Kesimpulan}

Berdasarkan hasil penelitian tugas akhir ini, dapat disimpulkan bahwa :

Dari keseluruhan alternatif penarikan garis batas maka akan merubah juga batas pengelolaan laut daerah secara keseluruhan khususnya antara daerah Kota Surabaya dan Kabupaten Gresik, karena pada prinsipnya keberadaan Pulau Galang ini berpengaruh pada batas laut di kedua daerah tersebut. Terdapat 4 (empat) alternatif kepemilikan Pulau Galang berdasarkan penarikan batas pengelolaan laut daerah sesuai Peraturan Menteri Dalam Negeri Nomor 76 Tahun 2012, diantaranya :

a. Penarikan batas pengelolaan laut daerah dengan alternatif Pulau Galang dianggap tidak ada, sehingga dihasilkan bahwa Pulau Galang menjadi dua kepemilikan yaitu Kota Surabaya dengan luas $83.091 \mathrm{~m}^{2}$ atau 8,3 hektar dan Kabupaten Gresik yakni 20.234 $\mathrm{m}^{2}$ atau 2,0 hektar

b. Penarikan batas pengelolaan laut daerah dengan alternatif Pulau Galang dibagi sama luas, sehingga dihasilkan bahwa Pulau Galang menjadi dua kepemilikan yaitu Kota Surabaya dan Kabupaten Gresik dengan luas yang sama yaitu $51.663 \mathrm{~m}^{2}$ atau 5,16 hektar

c. Penarikan batas pengelolaan laut daerah dengan alternatif Pulau Galang masuk daerah Kota Surabaya, dengan demikian kepemilikan Pulau Galang seutuhnya ada di pihak Kota Surabaya yakni sebesar 103.326 $\mathrm{m}^{2}$ atau 10,3 hektar

d. Penarikan batas pengelolaan laut daerah dengan alternatif Pulau Galang masuk daerah Kabupaten Gresik, dengan demikian kepemilikan Pulau Galang seutuhnya ada di pihak Kabupaten Gresik yakni sebesar $103.326 \mathrm{~m}^{2}$ atau 10,3 hektar

\section{DAFTAR PUSTAKA}

Adnyana, I., Arsana, I., dan Sumaryo. 2006. "Delimitasi Batas Maritim antara Provinsi Bali dan Provinsi Nusa Tengga Barat : Sebuah Kajian Teknis". Yogyakarta : Jurusan Teknik Geodesi dan Geomatika FT UGM

Amhar, Patmasari, dan Kencana, 2001, “Aspek-aspek Pemetaan Batas Wilayah Sebuah Tinjauan Komprehensif", Geo Informatika, Vol. 8 No. 1, Agustus 2001.
Departemen Dalam Negeri dan Otonomi Daerah. 2001. "Rancangan Peraturan Pemerintah tentang Batas Daerah". Jakarta.

International Hydrographic. 2006. "A Manual On Technical Aspects of The United Nations Convention On The Law Of The Sea - 1982 : Special Publication No. $514^{\text {th }}$ Edition". Bureau Monaco

Kementrian Dalam Negeri. 2012 a. "Peraturan Menteri Dalam Negeri Republik Indonesia Nomor 76 Tahun 2012 Tentang Pedoman Penegasan Batas Daerah". Jakarta.

Kementrian Dalam Negeri. 2012 b. "Lampiran Peraturan Menteri Dalam Negeri Republik Indonesia Nomor 76 Tahun 2012 Tentang Pedoman Penegasan Batas Daerah". Jakarta.

Pemerintahan Pemerintah Kota Surabaya. 2003. "Bahan Kajian Penyelesaian Masalah Pulau Galang Antara Kota Surabaya dengan Kabupaten Gresik : Arsip Bagian Pemerintahan Kota Surabaya". Surabaya

Pujiastuti, Fusy. 2009. "Aspek Geodestik dalam Penarikan Batas Wilayah Laut Daerah (Studi Kasus : Perairan Selat Madura)". Surabaya : Jurusan Teknik Geomatika FTSP ITS

Pusat Pemetaan Batas Wilayah. 2012. Laporan Tahunan Pusat Pemetaan Batas Wilayah 2012. Bogor : Badan Informasi Geospasial

Rais, J., 2003, "Studi Kasus Batas Wilayah Laut antara Provinsi Sumatera Selatan dan Provinsi BangkaBelitung", Seri Reformasi Hukum, Koleksi Dokumen Proyek Pesisir 1997-2003.

Republik Indonesia. 2004. "Undang-Undang Republik Indonesia Nomor 32 Tahun 2004 Tentang Pemerintahan Daerah". Jakarta.

Safitri, D.A. 2007. "Studi Penentuan Batas Maritim antara Dua Negara Berdasarkan Undang-Undang yang Berlaku di dua Negara yang Bersangkutan (Studi Kasus : NKRI dan RDTL)". Surabaya : Jurusan Teknik Geomatika FTSP ITS 